\title{
Histological Structure of The Thoracic and Abdominal Region Skin of The Etawah Goats Cross Breed
}

\author{
(STRUKTUR HISTOLOGI KULIT REGIO THORAK DAN ABDOMEN KAMBING \\ PERANAKAN ETAWAH)
}

\author{
Ni Ketut Suwiti ${ }^{1 *}$, Mergayanti Yudanta Eka Putri ${ }^{2}$, Putu Suastika ${ }^{1}$, \\ Ni Luh Eka Setiasih ${ }^{1}$, Luh Gde Sri Surya Heryani ${ }^{3}$, Ni Nyoman Werdi Susari ${ }^{3}$ \\ ${ }^{1}$ Departement of Histologi, Faculty of Veterinary Medicine, Udayana University. \\ ${ }^{2}$ Praktisi Dokter Hewan di Kota Mataram, Lombok Nusa Tenggara Barat. \\ ${ }^{3}$ Departement of Anatomy and Embriology Faculty of Veterinary Medicine, Udayana \\ University. J1. PB. Sudirman, Denpasar, Bali.*Email: nk_suwiti@unud.ac.id
}

\begin{abstract}
There have been studies of the histological structure of male and female goat skins. The histological structure and histomorphometry were taken from two region of skin, which is the thorax and abdomen. The Samples were collected from 2-3 years old Etawah goat, and than was stained using a HarrisHematoxilin Eosin method. The data were analysis based on the region and sex. The results showed that the histological structure of Etawah cross breed consists of three layers were epidermis, dermis, and hipodermis respectively. The epidermis composed by stratum corneum, granulosum, spinosum, and basal. We were found keratin layer on the surface of epidermis. The dermis consists of papillare and reticulare stratum. That was found many sebaceous glands, sudorifera gland, pili muscle, hair follicles, blood vessels, and collagen fibers. The hypodermis layers of Etawah cross breed females skin mostly consists of the fatty tissue, whereas in males we have found thick and horizontally arranged connective tissue. The skin layer on male Etawah cross breed, thorax region thicker than the abdomen. The region and sex may have an effect on the histology structure and histomorphometry of Etawah cross breed skin.
\end{abstract}

Keywords: Etawah cross breed; skin; thorax; abdomen; histology; histomorphometry

\section{INTRODUCTION}

Etawah cross breed is a cross breed goat between etawah goat that originated from India and local Indonesian goat and spread across almost in whole Indonesia (Pamungkas et al., 2009). Etawah cross breed is one of ruminansia livestock that produce better quality meat compared to other goat breeds. The meat quality can be assessed from the skin condition (Rospond, 2008), namely smooth, clean, moist, sagginess, and excess from skin disease (Arbi, 2009). Skin examination could be done macroscopic by observing the colour changes of skin or lesion, and microscopic which can detect diseases such as Foot and mouth desease, scabies, demodicosis, ringworm, goat pox, and anthrax (Choliq et al., 2014; Darmono and Hardiman, 2011).
The skin is one of the largest and the most important organic system of the body and acts as a barrier between the outside world and the internal environment (Kumar et al., 2012). It is responsible for protection, thermoregulation, external sensory awareness, immunological defence, wound healing, perception and excretion. The skin is an effective barrier which prevents desiccation of electrolytes and macromolecules from the body (Rospond, 2008; Mustakin and Kurniawan, 2010). Histologically skin is composed by three layers, epidermis, junction layer which consist dermis, and hypodermis (subcutis) which consist of loose connective tissue. The skin composed by four basic layers, has various type of epitel primarily squamous epitel with corneum layers, connective tissue, muscle which can be found in dermis, and nerve tissue, that can be found 
on skin forming free nerve ending and nerve body (Kalangi, 2013). The skin is the multi layered organ and its layers get modify depending upon the species, habitat and body region of the animal. Enough number of blood vessels, nerves, muscles and glands are present in different layers of skin (Simone et al., 2010). The importance role of skin for livestock, in addition to the body's defense organs, is also an indicator of health and meat production. Therefore, it is important to learn histological structure and histomorphometry of goat skin especially Etawah cross breed.

\section{MATERIALS AND METHODS}

\section{Samples}

The samples were taken from Kampung Jawa Denpasar slaughter houses - Bali Island. Twenty skin samples (with size of 1 "x1" cm) of Etawah cross breed's, from each region, were collected from male and female at the age of 2-3 years. The samples were fixed in $10 \%$ neutral buffered formalin for about 48 hours (Lewellyn, 2009).

\section{Haematocylin Eosin staining}

The samples were processed through ascending grades of alcohol benzene schedule as per standard methods and emblocked in paraffin wax of $60^{\circ} \mathrm{C}$ melting

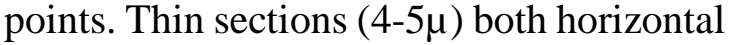
and vertical were cut with the help of rotatary microtome and stained with Haematocylin Eosin (Kiernan, 2008). Observation to histology struture is done by five-field view Carl Zeiss teaching microscope, with objective magnifying of 10x, 45x, and 100x. Histology structure variable consisting observation of epidermis, dermis, hypodermis covering the sel structure, muscle fiber, fat cell, and connective tissue. Histomorfometri is done by measuring the thickness of epidermis and dermis layers.

\section{Statistical analysis}

The data of histological structure was analyzed by kualitative deskriptive. The histomorphometry data is tabulated in the mean \pm standard deviation (SB) and analyzed using $\mathrm{T}$ test.

\section{RESULT AND DISCUSSION}

The histology structure of male and female skin from Etawah cross breed consist of three layers; epidermis, dermis, and hypodermis are shown in Fig.1 and Fig.2. Epidermis is formed by stratum corneum, granulosum, spinosum, and basale. The dermis structure of the male duck's was denser than the female. The fatty tissue of the female goat's hipodermis skin largerly by fat cells.

The epidermis of abdomen region in male Etawah cross breed formed by one to five layers cells, and region thorax formed of two to five cells, made mostly out of keratinocytes, along with three other different and less abundant cells (Fig 2). The epidermis of male etawah cross breed which indented to inner area of dermis has thicker layer compared to other skin regio. Meanwhile in female goat this difference is not found.

Histologic structure of dermis is shown in Fig 3. We were found, the dermis layer consisted of stratum papilare and retikulare. Stratum papilare is formed by dense connective tissue, collagen fiber, sebasea gland, sudorifera gland. Stratum retikulare is formed by skeletal muscle phili, hair follicle, and blood vessel. In female consisted more glands compared to male Etawah cross breed.

The hipodermis of Etawah cross breed skin consist of connective tissue, fat cells, collagen, and blood vessel, presented Fig 4 . In female commonly fat cells can be found more than male Etawah cross breed. In male characterized by majority of its layer is consist of connective tissue, aligned parallel forming thick and clear line, which can be found in thorax regio.

\section{Histomorphometry of Etawah cross breed skin}

Histomorfometri measurement of etawah cross breed skin is shown in Table 1. Epidermis and dermis of male Etawah cross breed from thorax regio, is thicker 
than female goat $(\mathrm{P}<0.05)$. Meanwhile dermis layer of abdominal regio of male goat and female goat doesn't have significant difference in thickness.

The Histologic structure of skin from Etawah cross breed, consist of epidermis, dermis and hypodermis (Arda et al., 2014) with varying thickness depend on sex and regio of skin (Mir et al., 2011). The epidermis is outermost structure, covered by keratin, composed respectively by squamous stratified keratinized epithelium

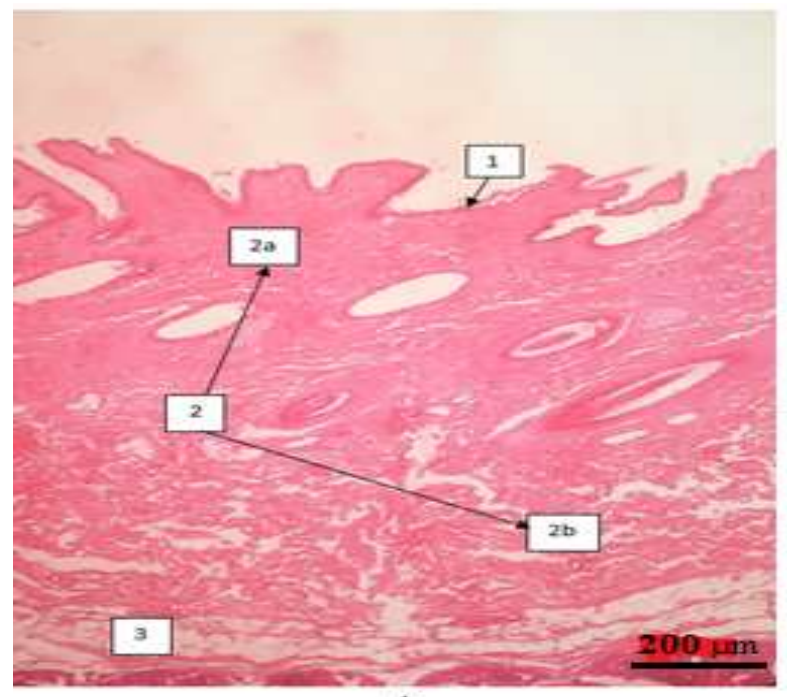

A
(Tarun et al., 2010; Iyomasa et al., 2014). which formed by four layers, which are stratum corneum, granulosum, spinosum, and basale. There is no stratum lusidum in epidermis layer. The absence of stratum lucidum is because of the skin regio that stratum lucidum is commonly found in skin regio that has a lot of contact and friction for example feet sole (Bhattacharya et al. 2003). Epidermis layer thickness are vary, depends on regio and sex (Mir et al., 2011).

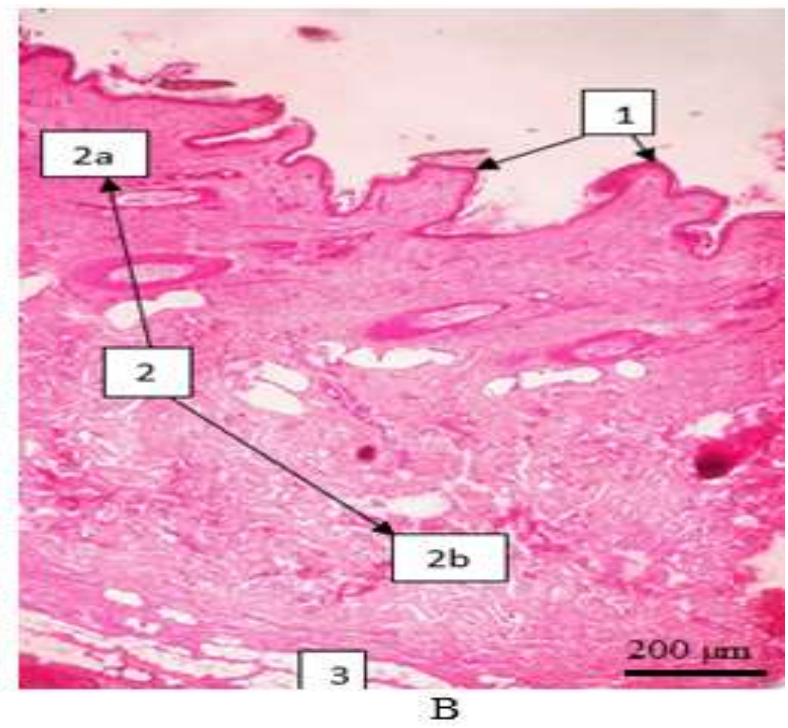

Fig 1. Histologic structure of female Etawah cross breed (H\&E, X40). Abdomen region (A) thorax region (B). Epidermis (1), Dermis (2), St. papilare (2a), St. retikulare (2b), Hypodermis (3).

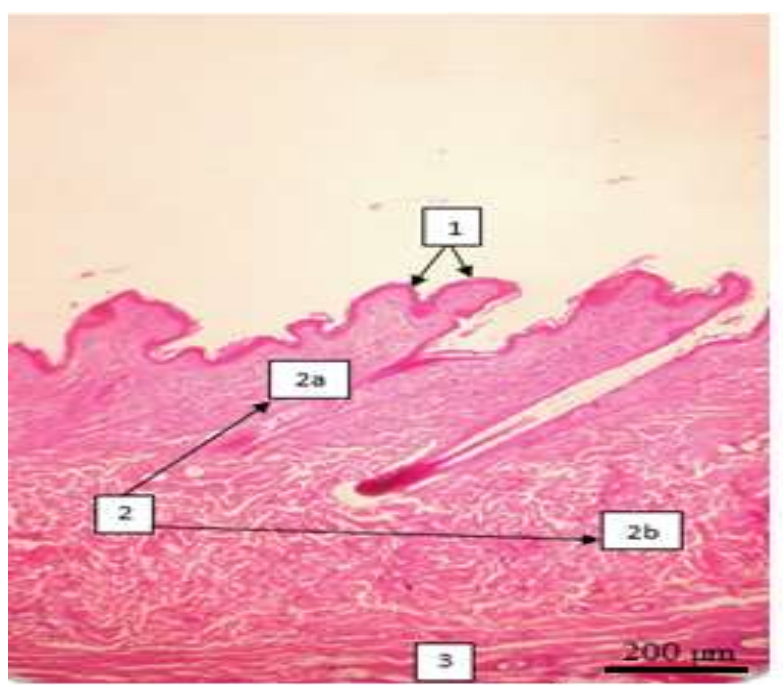

A

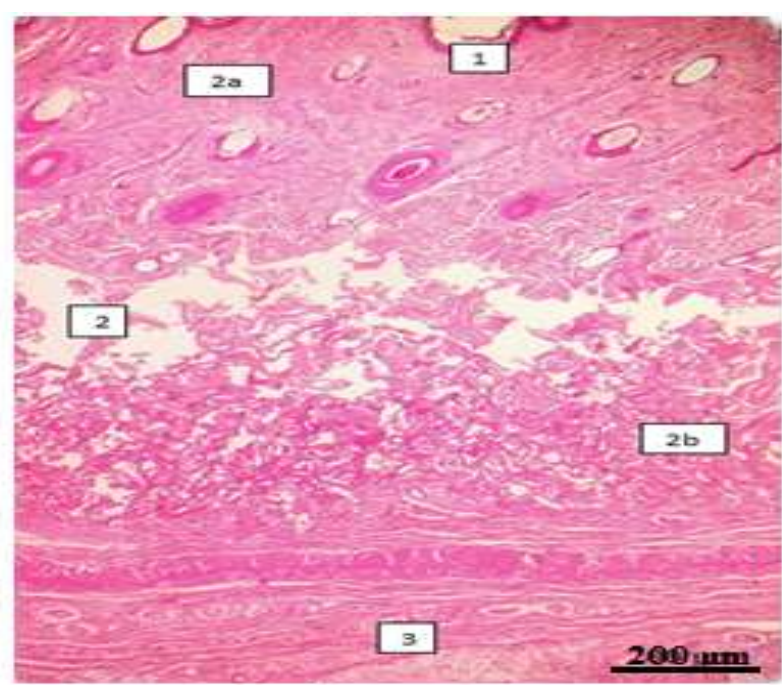

B 
Fig 2. Histologic structure of male Etawah cross breed (H\&E, X40). Abdomen region (A), thorax region (B). Epidermis (1), Dermis (2), St papilare (2a), St retikulare (2b), Hypodermis (3).

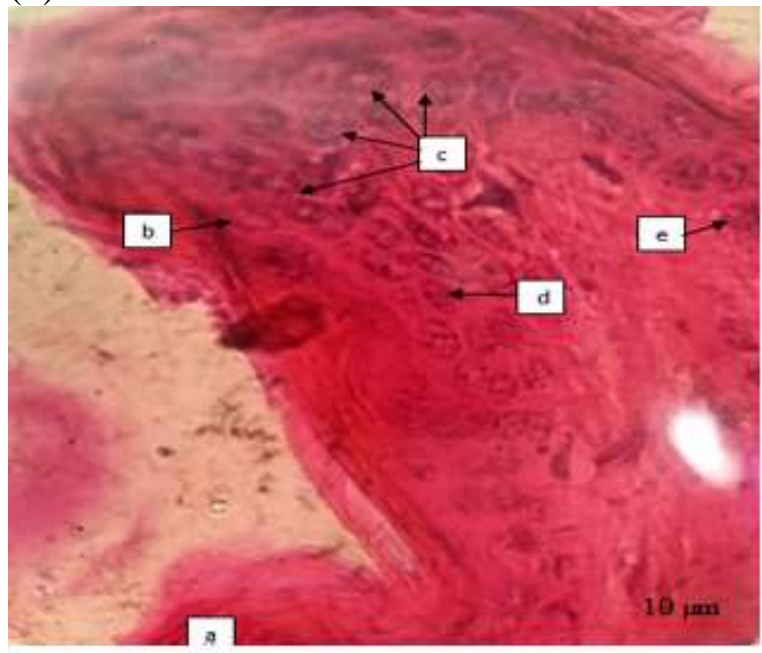

A

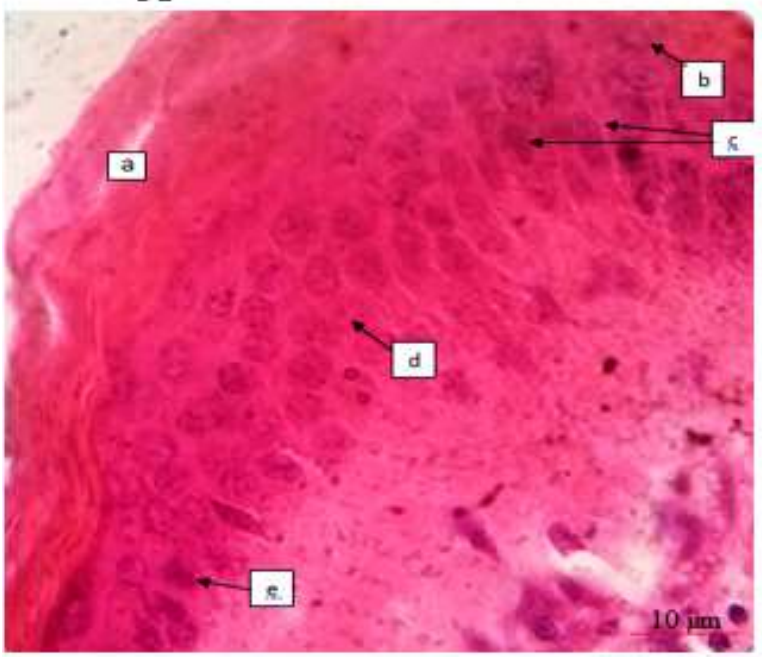

$\mathrm{C}$

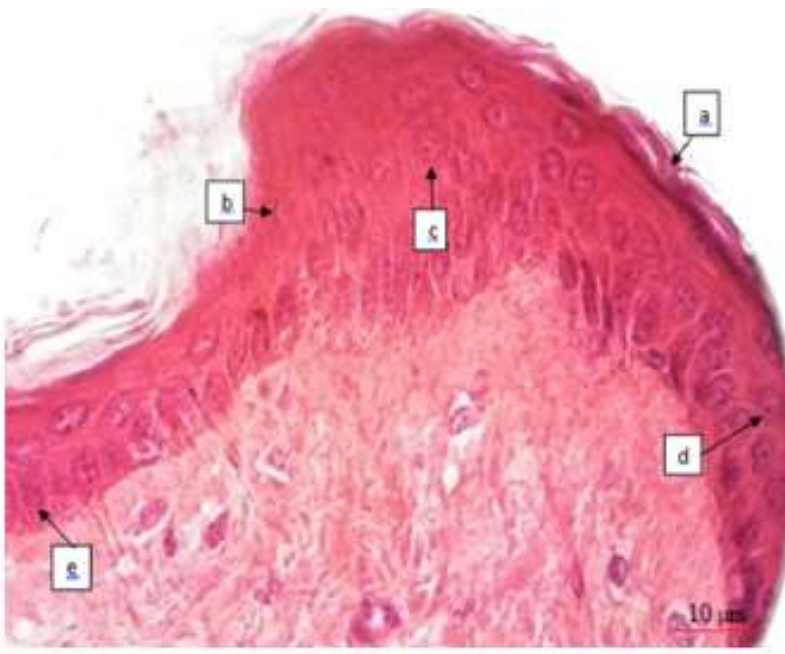

B

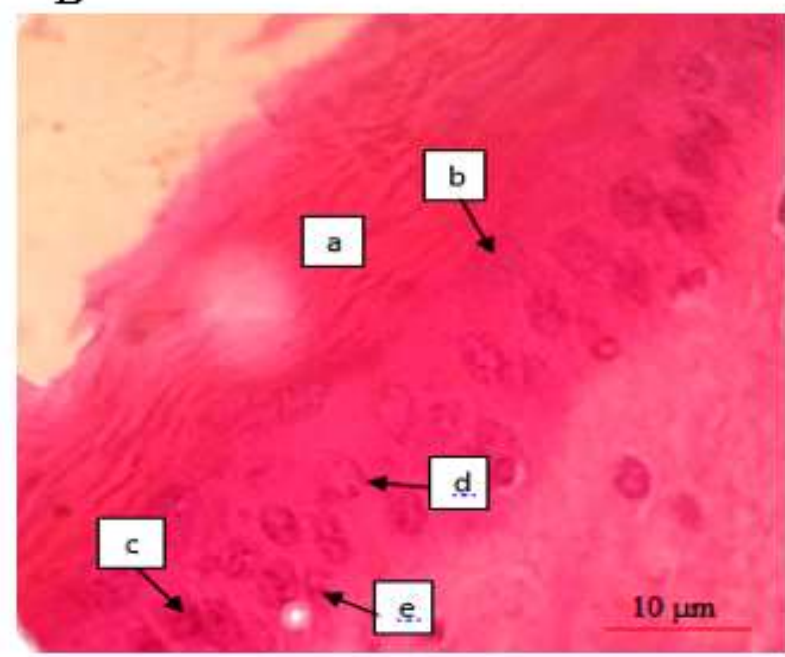

$\mathrm{D}$

Fig 3. Histologic structure of skin Etawah cross breed (H\&E, X1000.) female abdomen region (A), female thorax region (B), male abdomen region (C), male thorax region D). keratin (a), St. corneum (b), St. granulosum (c), St. spinosum (d), St. basale (e).

Table 1. Average thickness of epidermis and dermis $(\mu \mathrm{m})$ at different regions and sex of Etawah cross breed (Mean \pm SE)

\begin{tabular}{llcc} 
Sex & Region & $\begin{array}{c}\text { Epidermis } \\
(\mu \mathrm{m})\end{array}$ & Dermis $(\mu \mathrm{m})$ \\
\hline \multirow{2}{*}{ Male } & Thorak & $39.1 \pm 0.4^{\mathrm{a}}$ & $2911.05 \pm 164.7^{\mathrm{a}}$ \\
& Abdomen & $31.7 \pm 0.8^{\mathrm{b}}$ & $1828.7 \pm 39.9^{\mathrm{b}}$ \\
\hline \multirow{2}{*}{ female } & Thorak & $37.5 \pm 1.1^{\mathrm{c}}$ & $2445.6 \pm 311.9^{\mathrm{c}}$ \\
& Abdomen & $35.9 \pm 0.4^{\mathrm{d}}$ & $1917.05 \pm 82.1^{\mathrm{b}}$ \\
\hline
\end{tabular}

Note: values between the regions with different superscript (a and b) differ significantly $(\mathrm{P}<0.05)$ 


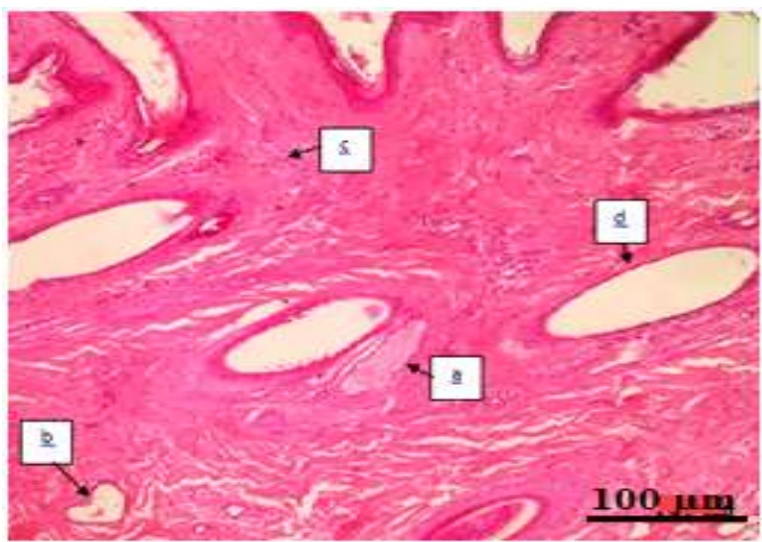

A

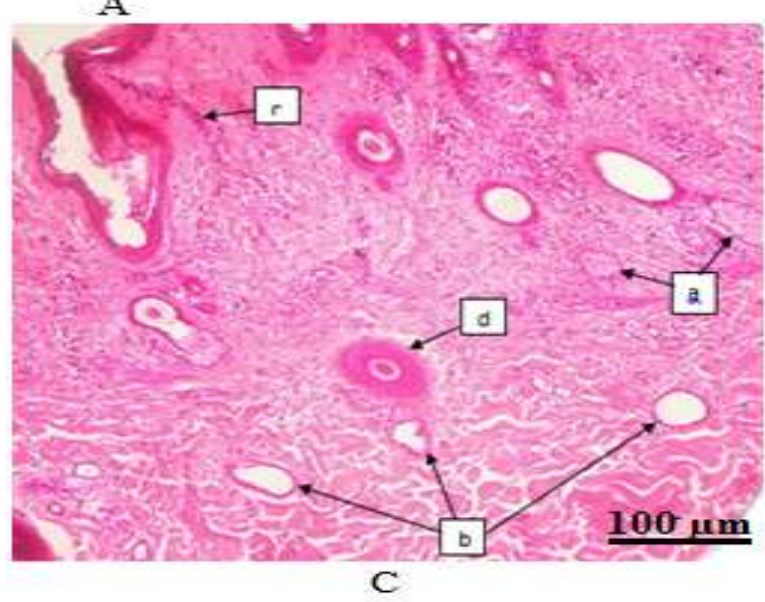

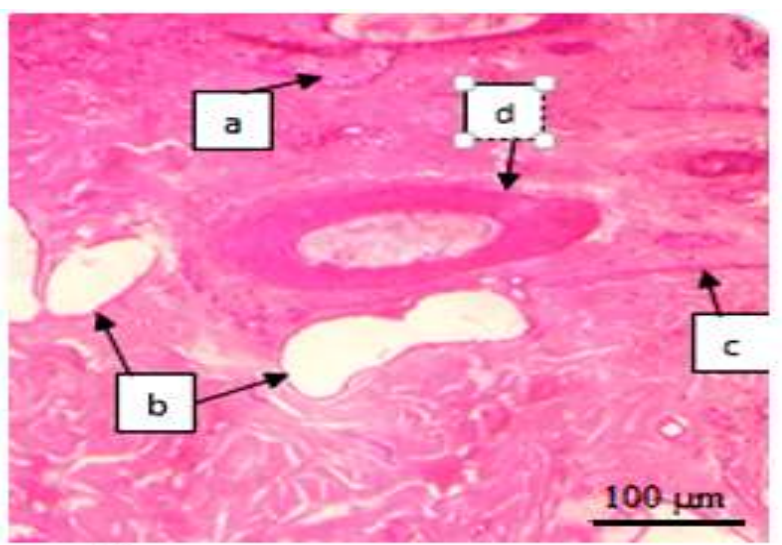

B

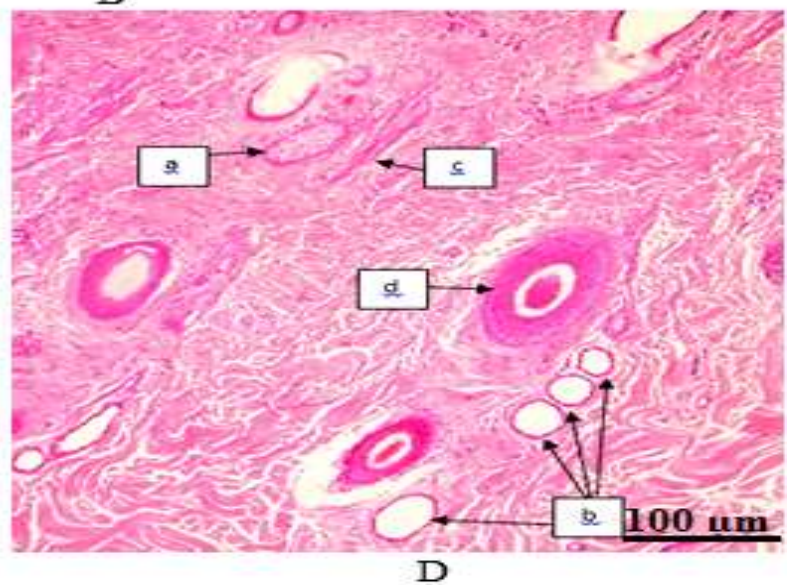

Fig 4. Histological structure of dermis. Female: abdomen region (A), thorax region (B) and male: abdomen region (C) thorax region (D), sebaceous glands (a), sudorifera glands (b), muscle (c), hair follicles (d) (H\&E, X100).

Stratum basale consist of membrane basale which separate epidermis from dermis that has simplex columnar layer. Cuboid or cylindric cells migrating to surface layer to supply superficial layer of cell (Mandage et al., 2003; Kapadnis and Bhosle, 2004).

Stratum spinosum is formed by $1-2$ layers of polyhedral with oval shaped core (Razvi et al., 2015) and stratum granulosum formed by 1-3 layers of epithel squamous. Bakerwali goat and Deccani goat in its skin is found to only have 1 layer of squamous cells and has a lot of basophilic gland which called keratohyalin gland (Razvi et al., 2015; Mandage et al., 2003)

Stratum corneum is the outermost layer of epidermis, consist of 1-2 layers of cells. Meanwhile in Deccani goat this outermost layer is different, its layer consist 4-5 layers
(Kapadnis and Bhosle, 2004). Cell in this layer is shaped flat and not containing nucleus (Razvi et al., 2015). In stratum corneum is found superficial cells which is stratum corneum that hydrated then peeled off (Kalangi, 2013; Jeffry et al., 2017).

There are keratinosit, melanosit, langerhans cell, and merker cell in epidermis. Keratinosit is epithel cell which undergo keratinization, producing water proof and protecting barrier. Melanosit is a small cell with long and thin dendritic located between stratum basal, and hair follicle. Langerhans cell is dendritic cell with irregular shape and has a role in immune system. Merkel cell is a cell that can be found in thick skin layer and hair follicle (Kalangi, 2013). 


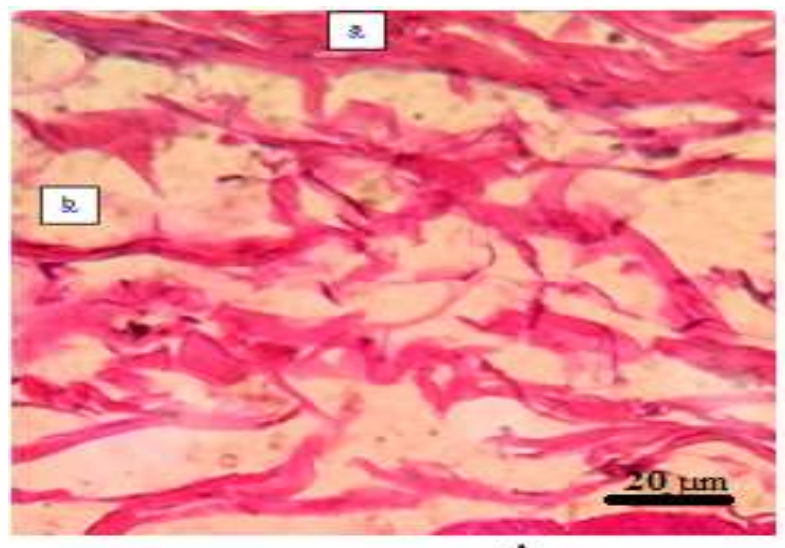

A
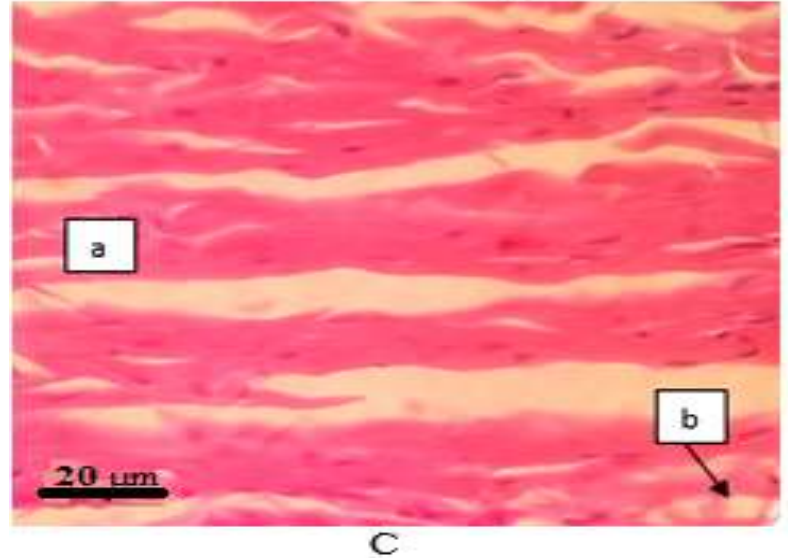

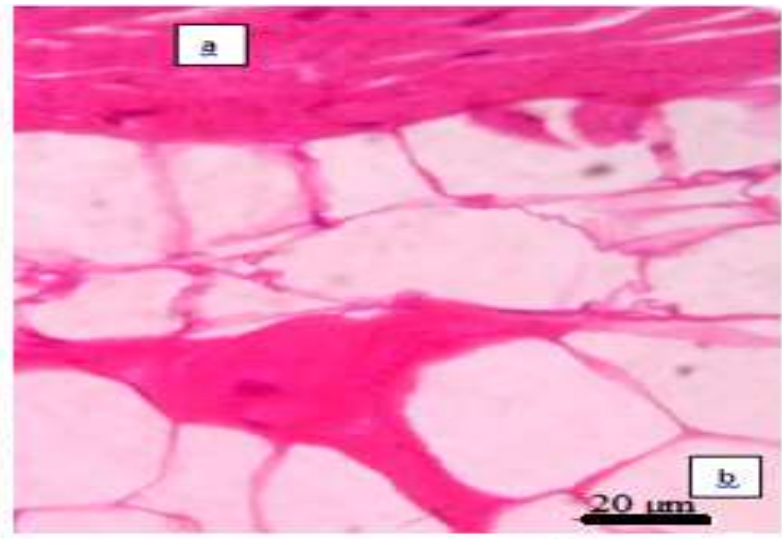

B

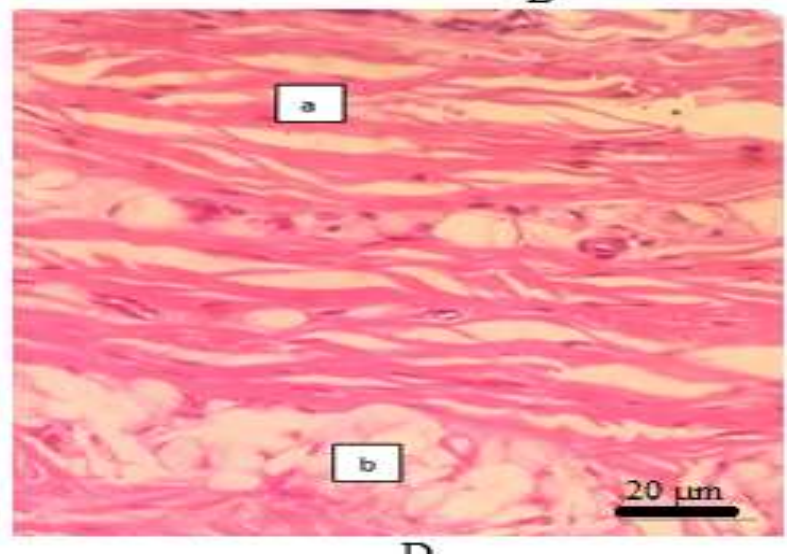

D

Fig 5. Histologic structure of hipodermis. Female: abdomen region (A), thorax region (B), and male: abdomen region (C), thorax region (D), Connective tissue (a), fat cells (b) (H\&E, X 400).

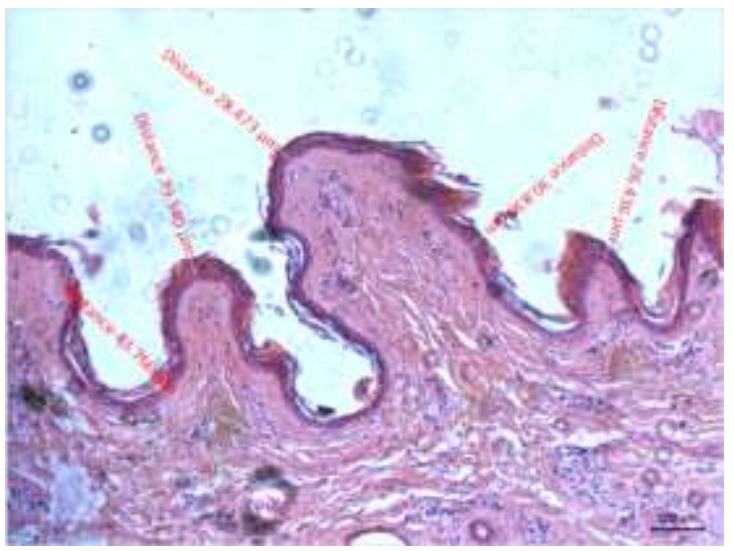

Fig 6. Histomofometri of female Etawah cross breed (HE X100).

The dermis is constituted mainly by collagen and could be divided into two layers with no distinct limits: the upper papillary dermis and the lower reticular dermis (Iyomasa et al., 2013). Dermis consist of solid connective tissue, collagen tissue, hair follicle, sebacea gland, and sudorifera gland (sweat gland), blood vessel and muscle phili (Dellmam and
Eurell, 1998). Reticulare layer is thicker than papilare layer which consis of hair follicle, skeletal muscle phili, sudorifera gland, and sebacea gland. Different situation is found in Merino goat, there is no gland in papilare layer (Warren et al., 2008). In horse, there are reports that stratum papilare has more cells, meanwhile in stratum retikulare consist more muscles. Muscle phili always connected to sebacea gland, usually around hair follicle in papilare layer of dermis (Kapadnis et al. 2005). Similar finding is found in White Rhinoceros (Jeffrey et al., 2017). In goat muscle phili is not only to have a role in straighting the hair but also stimulating other secretion product to secretion channel (Mobini, 2012).

Dermis layer of thoracal regio of male Etawah cross breed is thicker $(\mathrm{P}<0.05)$ than female, because of the dermis layer of male goat is consisted of clear, thick, dense 
connective tissue, and also in thoracal regio of male goat consisted a lot of hair, which cause a lot of follicle to be found. This situation caused an increase in collagen fiber to reduce skin elasticity (Mobini, 2012). Smooth collagen fiber is distributed irregularly in papilare layer meanwhile, the solid and rough collagen layer is forming the reticulare layer. Colagen fiber surround the hair follicle in retikulare layer (Razvi et al., 2015). In mammal skin, collagen is part of dermis which most abundant. Collagen has a role in skin layer forming (Mir et al., 2011)

Sebaceous gland has various shape; simple, branched, or compound olveolar in domestic animals (Aughey and Frye, 2001). In Etawah cross breed the shape of sebaceous gland is a mix between thoracic and abdominal region. This gland is always linked to hair follicle and located above the sudorifera gland (sweat gland) or papilare layer of dermis. Sebaceous gland mostly consisted of a simple cuboid layer, but in some regio consisted of simple squamous (Mobini, 2012; Jeffry et al., 2017).

The cells forming the sudorifera gland of goat is vary, because in domestic animal has various shape from saccular to tubular (Aughey and Frye, 2001). In Etawah cross breed goat, sudorifera gland shape is simple saccular. Secretion cells in sudorifera gland covered by simple squamous to cuboid epithelium (Mobini, 2012)

In this study, the hypodermis layer is not reported because of difficulty in measuremenet, the thickness can reach 1/4 skin thickness. Fat cells in female goat is found a lot more than in male goat. This is caused by the amount of fat cells is determined by gender, hormonal, and activity. Testoteron hormone in male goat can reduce the fat disposisition and repair the hair pigmentation, and also male goat from its activity is more acitve that female goat (Saka et al., 1997).

\section{CONCLUSION}

Thorax skin region of Etawah cross breed is thicker than abdomen. Skin epidermis indented inside the dermis area has thicker cell layers compared to other skin regio. Dermis layer consisted of dense connective tissue, collagen fibers, and found to have more sebaceous gland, sudorifera glands in female goat. In hypodermis layer male goat has more connective tissue which arranged horizontally, thick, and clear. Meanwhile in female is found to have more fatty tissue. Male skin is thicker than female etawah cross breed.

\section{REFERENCES}

Arbi P. 2009. Analisa Kelayakan dan Strategi Pengembangan Usaha Ternak Sapi Potong. Universitas Sumatera Utara, Medan.

Arda O, Goksugur N, Tuzun Y., 2014 Basic histological structure and functions of facial skin. Clin. Dermatol., 32(1): 313.

Aughey E, Frye FL. 2001. Comparative Veterinary Histology with Clinical Correlates. $1^{\text {st }}$. ed, Manson, London, 129-130.

Bhattacharya MK, Banerjee R, Singh KS, Guha RK, Ghosh RK. 2003. Histological and bio-metrical study on epidermis of non-descriptive buffalo (Bubalus bubalis). Indian J. Anim. Health., 42:151-155.

Choliq C, Setyo W, Sajuthi D, Wijaya A, Wulansari R, Lelana A. 2014. Diagnostik Klinik Hewan Kecil: Bab VII Kulit dan Rambut. PT Penerbit IPB Press Edisi I Cetakan Ketiga, Kampus IPB Taman Kencana Bogor.

Darmono, Hardiman, 2011. Penyakit Utama Yang Sering Ditemukan Pada Ruminansia Kecil (Kambing Dan Domba). Workshop Nasional Diversifikasi Pangan Daging Ruminansia Kecil 2011.

Dellmann HD, Eurell JA. 1998. Text Book of Veterinary Histology. $5^{\text {th }}$ ed. London: Williams and Wilkins; p. 303-332

Iyomasa MM, Caroline JL, Camargo ER, Paulo J, Issa M, Dias FJ, Watanabe I, Iyomasa DM. 2014. Ultrastructure and 
light microscope analysis of intact skin after a varying number of lowlevel laser irradiations in mice. J. BioMed Res. Int., 2014(506051): 1-8.

Jeffry HP, Ruiz S, Rodriguez JRS, Hall MI. 2017. Histologycal study of white Rhinoceros integument. J. Plos ONE., 12(4).

Kalangi SJR. 2013. Histologi kulit. J. Biomed., 5(3): 12-20.

Kapadnis PJ, Bhosle NS. 2004. Microscopic anatomy of the integument of osmanabadi goat. Indian Vet. J., 81: 912-914.

Kapadnis PJ, Bhosle NS, Mamade CS. 2005. Study in Connective Tissue Fibre in Neck Skin of Goat. Indian J. Anim. Res., 39: 60-62.

Kiernan JA. 2008. Histological and Histochemical Methods: Theory and Practice. 4th ed. Bloxham, UK: Scion.

Kumar N, Kumar P, Prasad K, Nayak S. 2012. A histological study on the distribution of dermal collagen and elastic fibres in different regions of the body. Int. J. Med. Medic. Sci., 4(8): 171-176.

Lewellyn BD. 2009. Nuclear staining with alum-hematoxylin. Biotech. Histochem. 84: 159-177.

Mandage ST, Bhosle NS, Kapadnis PJ, Mamade CS. 2003. Microscopic anatomy of the integument of the decani sheep. Indian J. Vet. Anatomy., 15: 6869.

Mir SA, Satyamoorthy OR, Ramesh G and Balachandran C. 2011. Micrometrical studies on the skin of madras red sheep (Ovis aries) in different age groups. Tamilnadu J. Vet. Anim. Sci., 7(1): 2328.

Mobini B. 2012. Histology of the skin in an iranian native breed of sheep at different ages. J. Vet. Adv., 2(5): 226231.

Mustakin ASW, Kurniawan AP. 2010. Perbedaan kualitas kulit kambing peranakan etawa (pe) dan peranakan boor ( $\mathrm{pb}$ ) yang disamak krom. J. Ternak Tropika., 11(1): 38-50.

Pamungkas FA, A Batubara, M Doloksaribu, E Sihite. 2009. Potensi Beberapa Plasma Nutfah Kambing Lokal Indonesia. Petunjuk Teknis. Pusat Penelitian dan Pengembangan Peternakan Badan Penelitian dan Pengembangan Pertanian Departemen Pertanian.

Razvi R, Shalini S, Kamal S, Rohin S. 2015. Histomorphological and histochemical studies on the different layers of skin of bakerwali goat. J. Appl. Anim. Res., 43(2): 208-213.

Rospond RM, Goeser AL. 2008. Kulit, Rambut dan Kuku. Terjemahan oleh Benediktus Yohan, D. Lyrawati 2009.

Rusfidra. 2007. Paradigma Baru Pembangunan Peternakan; Membanguna Peternakan Bertumpu pada Ternak Lokal. Bogor: Cendekia Publishing House.

Simone C, Orpheu, Pedro S, Coltro GP, Scopel DS, Gomez CJ, Rodrigues, Miguel LA, Modelin, Joel F, Rolf G, Marcos C, Ferreira. 2010. Collagen and elastic content of abdominal skin after surgical weight loss. Obesity Surg., 20(4): 480-486

Suwiti NK, 2010. Deteksi histologik kesembuhan luka pada kulit pasca pemberian daun mengkudu (Morinda citrofilia linn). Bul. Vet. Udayana., 2(1): 1-9.

Tarun KG, Fabíola X. Domingos V, Maria F, AlmeidaV, Adalberto L. 2010. Histochemistry and functional organization of the dorsal skin of Ancistrus dolichopterus (Siluriformes: Loricariidae). J. Neotropical Ichthyol., 8(4): 877-884

Warren GH, James PJ, Neville AM. 2008. A morphometric analysis of the changes with age in the skin surface wax and the sebaceous gland area of merino sheep. Aus. Vet. J., 60: 238-240. 